Research article

\title{
Incomplete gastric metaplasia in children with insulin-dependent diabetes mellitus and celiac disease. An ultrastructural study Marina Bertini ${ }^{1}$, Andrea Sbarbati ${ }^{* 2}$, Enrico Valletta ${ }^{1}$, Leonardo Pinelli ${ }^{1}$ and Luciano Tatò ${ }^{1}$
}

\author{
Address: ${ }^{1}$ Department of Pediatrics and and ${ }^{2}$ Institute of Anatomy and Histology University of Verona, Verona, Italy \\ E-mail: Marina Bertini - bertinimarina@hotmail.com; Andrea Sbarbati* - sbarbati@borgoroma.univr.it; Enrico Valletta - hwwval@tin.it; \\ Leonardo Pinelli - leonardo.pinelli@univr.it; Luciano Tatò - luciano.tato@univr.it \\ *Corresponding author
}

Published: 25 June 2001

BMC Clinical Pathology 2001, I:2

This article is available from: http://www.biomedcentral.com/I472-6890/I/2

(c) 200 I Bertini et al, licensee BioMed Central Ltd.
Received: 4 April 2001

Accepted: 25 June 2001

\begin{abstract}
Background: The association of insulin-dependent diabetes mellitus (IDDM) and celiac disease (CD) has been widely reported in children but the relationship between the two conditions is incompletely understood. Moreover, specific studies on intestinal biopsies of patients with the association of the two diseases are still lacking.

Methods: We studied the ultrastructure of the duodenal mucosa in 12 patients with both IDDM and CD.

Results: All patients had either total or partial atrophy of duodenal mucosa. In seven subjects, an accumulation of electrondense granules in the apical cytoplasm of groups of enterocytes was found. In four of them, a double population of granules existed (mean diameter: 400-800 nm and 100-200 $\mathrm{nm}$ respectively) showing a biphasic pattern. In the other three patients, only smaller granules ( 100 $200 \mathrm{~nm}$ ) were found in the enterocytes.

Conclusions: The present work suggests that patients with IDDM/CD may represent a subgroup in the context of the CD population. Intestinal biopsies of such individuals often show accumulation of electrondense granules in the apical cytoplasm of enterocytes that can be interpreted as incomplete gastric metaplasia.
\end{abstract}

\section{Introduction}

The association of insulin-dependent diabetes mellitus (IDDM) and celiac disease (CD) has been widely reported in children $[1,2,3]$. The prevalence of $C D$ in patients with IDDM is significantly higher than that found in the general population (about 1:300), ranging between 1.3 and $19 \%[4,5,6,7,8,9,10,11,12]$. Although the relationship between the two conditions is incompletely understood $[13,14,15]$, previous genetic and immunogenetic studies suggested a common autoimmune pathogenesis for tis- sue damage $[16,17,18]$. Usually, IDDM onset precedes that of CD $[18,19]$ and it was demonstrated that immunological markers of CD (i.e. antigliadin (AGA) and antiendomysial (EmA) antibodies) can appear years after the diagnosis of IDDM $[10,20]$. In patients with IDDM, regular serological screening can lead to diagnosis of $C D$ in an early phase of mucosal lesion when the subjects are still asymptomatic $[17,21,22,23]$. 
Specific studies on intestinal biopsies of patients with the association of the two diseases have not yet been reported in the literature. Therefore, we performed an ultrastructural study in a group of patients with IDDM and $\mathrm{CD}$ in order to evaluate the pattern of mucosal lesion.

\section{Methods}

The 267 patients (at December 1997) with IDDM followed at the Diabetic Center of the Pediatric Department of Verona have been regularly screened for $C D$ since 1992. In all patients IgA and IgG AGA (EIA method) and/or IgA EmA (IFA method) were evaluated and in the positive subjects a duodenal biopsy was obtained. Twelve patients (7 males, age range 2.6-20.4 years) of 18 with IDDM and histological diagnosis of CD had also ultrastructural evaluation of their biopsy sample and were therefore included in the study group. Some clinical features of these patients are reported in the Table. All patients fulfilled current criteria for the diagnosis of IDDM (C-peptide levels $\leq 0.5 \mathrm{nmol} / \mathrm{I}$ ) and CD (positive AGA and/or EmA and consistent histological lesion).

Endoscopy was performed in the second duodenal portion using an Olympus GIF-XP1O gastroscope. Olympus FB-19K forceps were used for biopsies. For histology, samples were fixed in $4 \%$ neutral formalin and embedded in paraffin. For transmission electron microscopy (TEM), the specimens were fixed in $2.5 \%$ glutaraldehyde in Sorensen's buffer for two hours, postfixed in 1\% osmium tetroxide in Sorensen buffer for one hour, dehydrated in graded ethanols, embedded in epon-araldite and cut with a Ultracut E ultramicrotome (Reichert). Ultrathin sections were stained with lead citrate and uranyl acetate and observed under a EM10 electron microscope (Zeiss). Sixteen biopsies of children with CD (files of the Institute of Anatomy and Histology) were taken as a control group and treated accordingly to those of patients with IDDM/CD.

\section{Results}

Eleven of the 12 patients with IDDM/CD had no intestinal symptoms. Only one patient (\# 7) had mild diarrhea in the month before CD diagnosis. Histological and ultrastructural findings showed either a totally or partially atrophic duodenal mucosa in all patients (Table). In a single case (\# 5), a gastric metaplasia was found at histology. In another patient, histological examination revealed accumulation of PAS-positive material in small groups of enterocytes. In one child (\#1) Helicobacter pylori infection was observed at histological examination of the gastric mucosa.

At ultrastructural examination, enterocytes showed both reduced height and irregular microvilli in all patients. In 7 subjects (\# 1,2,3,4,5,6,10), we found an accumulation of electrondense granules in the apical cytoplasm of enterocytes. Such cells were positioned on the exposed surface, represented about the $8-10 \%$ of the epithelial cells and were usually disposed in small groups surrounded by "normal" enterocytes (Fig. 1,2). We did not observe any increase of lymphocyte counts among modified enterocytes.

Table: Clinical features of the study group.

\begin{tabular}{|c|c|c|c|c|c|c|c|}
\hline \multirow[t]{2}{*}{ Patient } & \multirow[t]{2}{*}{ Sex } & IDDM & $C D$ & \multirow[t]{2}{*}{$\operatorname{Ig} A$ AGA } & \multirow[t]{2}{*}{$\lg G A G A$} & \multirow[t]{2}{*}{$\lg A \mathrm{EmA}$} & \multirow[t]{2}{*}{ Histology } \\
\hline & & \multicolumn{2}{|c|}{ Age at diagnosis (yrs) } & & & & \\
\hline I & $M$ & 15.1 & 16.8 & + & + & + & TVA \\
\hline 2 & $M$ & 6.9 & 8.2 & + & + & + & TVA \\
\hline 3 & $M$ & 14.6 & 15.6 & + & - & + & PVA \\
\hline 4 & $\mathrm{~F}$ & 9.1 & 10.2 & + & + & + & TVA \\
\hline 5 & $\mathrm{~F}$ & 7.6 & 11.8 & + & + & nd & TVA \\
\hline 6 & $\mathrm{~F}$ & 1.8 & 2.6 & + & + & + & TVA \\
\hline 7 & $M$ & 3.7 & 5.7 & - & - & + & PVA \\
\hline 8 & $M$ & 10.6 & 17.2 & + & - & + & PVA \\
\hline 9 & $\mathrm{~F}$ & 6.6 & 8.8 & + & + & + & TVA \\
\hline 10 & $\mathrm{~F}$ & 6.9 & 20.4 & + & - & + & TVA \\
\hline II & $M$ & 7.1 & 9.6 & + & + & nd & TVA \\
\hline 12 & $M$ & 12.8 & 13.8 & + & + & + & PVA \\
\hline
\end{tabular}

\footnotetext{
+ : positive ; -: negative ; nd : not done. TVA : total villous atrophy ; PVA : partial villous atrophy.
} 


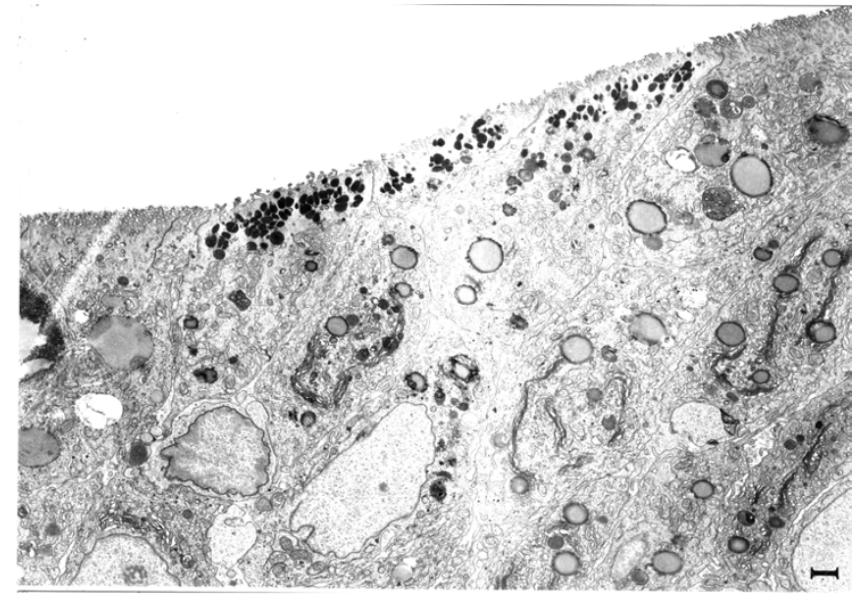

Figure I

TEM of the duodenal mucosa of patients with IDDM/ CD. Apical granules can be observed in a small group of cells in which the Golgi complexes are hypertrophyc, the microvilli are reduced in height and a lipidic accumulation is visible. Bar $=1000 \mathrm{~nm}$.

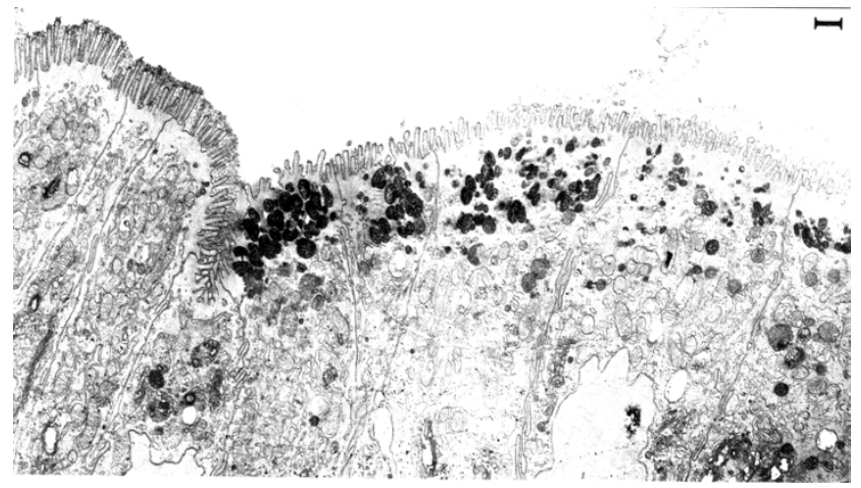

Figure 2

TEM of the duodenal mucosa of patients with IDDM/ CD. An area covered with secretory enterocytes is visible on the right. $\mathrm{Bar}=1000 \mathrm{~nm}$.

In 4 of these 7 patients, a double population of granules was visible (Fig. 3,4,5,6). The former had a diameter of 400-800 $\mathrm{nm}$ and an ovoid shape. A biphasic pattern was detected. The more electrondense component was at the periphery of the granule and generated a network in which less electrondense material was visible. The latter type of granules had a smaller diameter (100-200 nm) and a low-electrondensity round core. These granules were mainly at the periphery of the cell, close to the junctional apparatus. Both types of granules were found in cells with enlarged Golgi complexes in the supra-nuclear region. In the other 3 subjects, only granules of the smaller size (100-200 $\mathrm{nm}$ ) were found in the enterocytes. In 2 cases, enterocytes were sometimes filled with

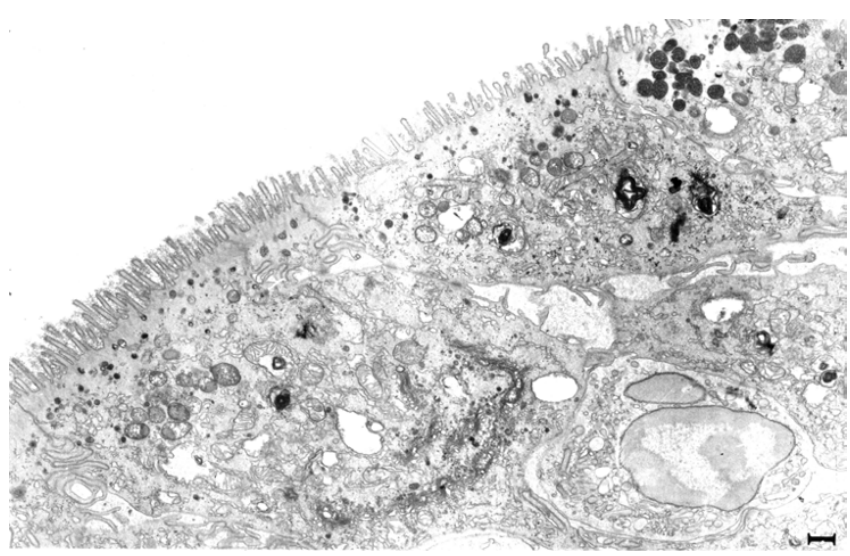

Figure 3

TEM of the duodenal mucosa of patients with IDDM/ CD. Enterocytes with large granules are shown on the right. On the left, enterocytes with small diameter granules in the apical cytoplasm. Bar $=625 \mathrm{~nm}$.

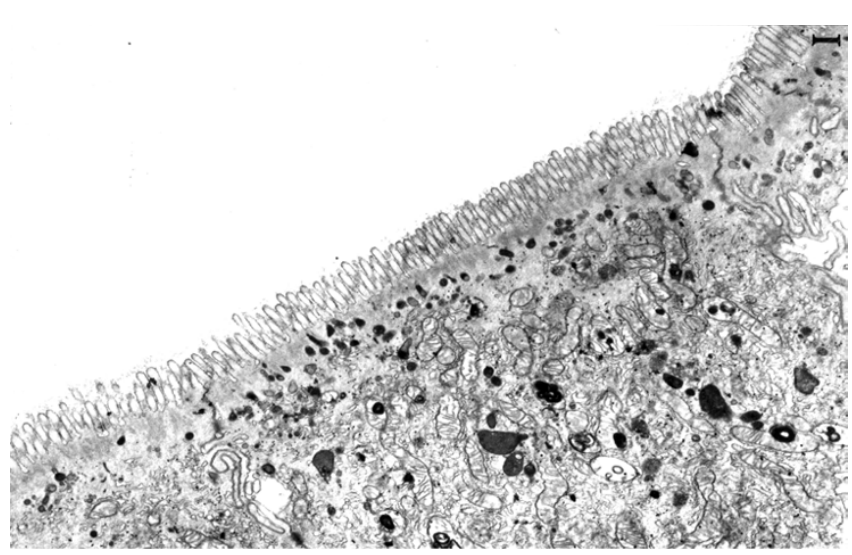

Figure 4

TEM of the duodenal mucosa of patients with IDDM/ CD. A group of elements with short microvilli and several small granules below the terminal web. Multilamellar lipidic inclusions (arrow) can be observed in the supranuclear portion of the cells. Bar $=500 \mathrm{~nm}$.

In the control group, optical and ultrastructural evaluation showed either total or partial atrophy of the duodenal mucosa, consistent with the diagnosis of CD. As a rule, no accumulation of secretory granules in the apical cytoplasm of the enterocytes was observed. In a single patient, mild accumulation of 100-200 $\mathrm{nm}$ granules was found.

\section{Discussion}

In the present work, we characterized the pattern of mucosal lesion in patients with IDDM and CD. In addition to the typical lesion of the celiac intestine (i.e., either total or partial mucosal atrophy), biopsies of these subjects showed a distinctive high frequency of modified entero- 


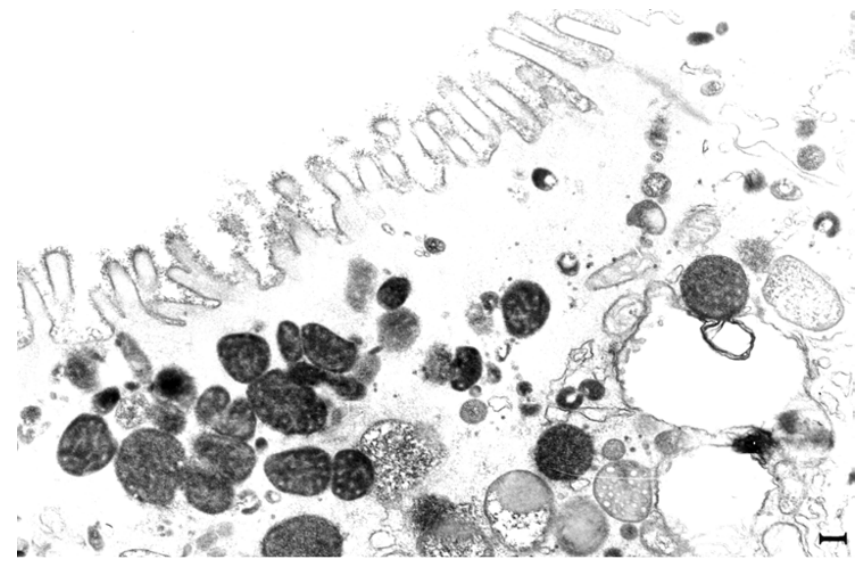

Figure 5

TEM of the duodenal mucosa of patients with IDDM/ CD. A cell with both large and small granules at high enlargement. Bar $=125 \mathrm{~nm}$.

cytes with accumulated electrondense granules. A similar pattern has not been previously described in $\mathrm{CD}$ and we did not found comparable aspects neither in the control group of CD patients nor in the ultrastructural examination of about 150 subjects (personal files).

The two main patterns of granule accumulation were found in $58 \%$ of our patients (in $33 \%$ and $25 \%$ of subjects respectively). Nevertheless, because of the small tissue area examined by electron microscopy, we cannot exclude that a similar patchy lesion could have been overlooked in some other subjects. The granules seemed to be secretory and not endocytotic, and also the enlarged Golgi complex we found in the modified enterocytes would suggest their secretory origin. However, it is not possible to be conclusive on this point, especially for the larger granules that have a heterogeneous content as in lysosomial compartments.

At high magnification, the internal pattern of large-diameter granules resembled that of the gastric superficial mucous cells. Elements with intermediate ultrastructural characteristics between secretory and absorptive cells have been described in intestinal metaplasia of the esophagus and stomach [24]. Therefore, accumulation of electrondense granules in four of our patients could be interpreted as an incomplete gastric metaplasia of duodenal mucosa, on the analogy of incomplete intestinal metaplasia described in the stomach $[25,26,27,28]$, esophagus [29] and esophagogastric junction [30]. Nevertheless, the pattern we described must be differentiated by other conditions in which PAS-positive material can be found in the apical portion of enterocytes. An accumulation of lysosomes is a rather aspecific event visible in several conditions of mucosal damage. Also in congenital

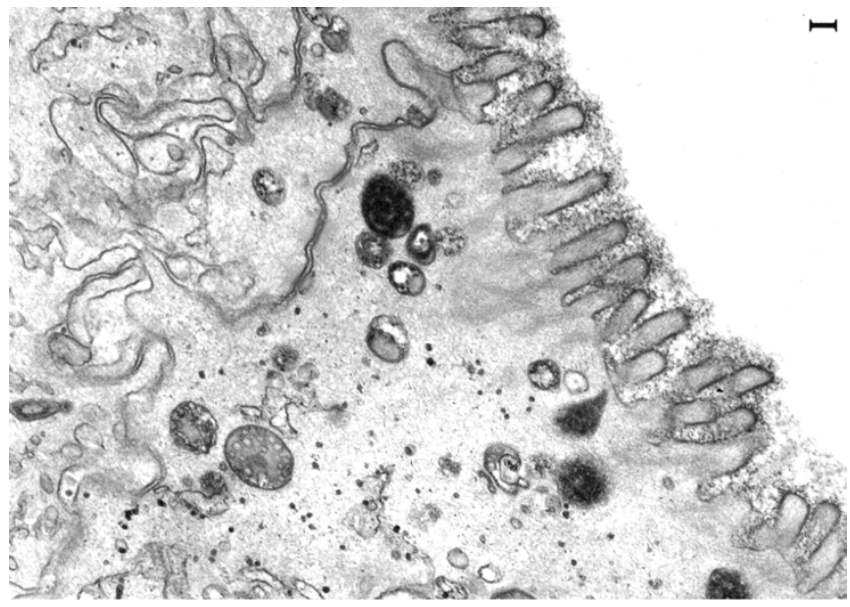

Figure 6

TEM of the duodenal mucosa of patients with IDDM/ CD. In these cells small granules are visible. A single large diameter granule shows atypical internal pattern. Bar $=156$ $\mathrm{nm}$.

microvillous atrophy, small, PAS-positive granules with a homogeneous internal pattern have been described, that seemed to be due to secretory material of the glycocalix [31]. Gastric metaplasia of the duodenum can be due to $H$. pylori infection [32] that seems to be frequent in diabetic patients. However, in our group a single patient with incomplete metaplasia showed $H$. pylori in the stomach.

In conclusion, the present work suggests that subjects with IDDM and CD represent a subgroup of CD patients characterized by a distinctive pattern of mucosal lesion. In our opinion, the lesion is not a true metaplasia because the complete transformation of the intestinal epithelium in a gastric-like surface is lacking. In incomplete gastric metaplasia, cells with accumulated granules maintain ultrastructural characteristics of enterocytes (i.e. terminal web, microvilli, glycocalix, etc.). Such a lesion seems rather to be the result of a process of phenotypic shifting by which the morphology of cells is $<<$ shifted $>>$ from an absorptive toward a secretive phenotype. We suggest that this transformation might be related to an abnormal intra-duodenal environment, perhaps secondary to anomalies of gastric emptying as reported in a high proportion of children with IDDM [33] and in animal models of this disease [34].

\section{List of abbreviations :}

IDDM : insulin-dependent diabetes mellitus

$\mathrm{CD}$ : celiac disease 
AGA: antigliadin antibodies

EmA : antiendomysial antibodies

TEM : transmission electron microscopy

\section{Acknowledgements}

The study was supported by a grant from Regione Veneto, Giunta Regionale, Ricerca Sanitaria Finalizzata, Venezia, Italy.

Competing interests

None declared

\section{References}

I. Payne WW: Coeliac disease and diabetes mellitus in the same patient. Gt Ormond Str J 1954, 8: 118

2. Komrower GM: Coeliac disease in a diabetic child. Lancet 1969 , I:1215

3. Walker-Smith JA, Grigor W: Coeliac disease in a diabetic child. Lancet 1969, I:1021

4. Cronin CC, Shanahan F: Insulin-dependent diabetes mellitus and coeliac disease. Lancet 1997, 349:1096-1097

5. Cronin CC, Feighery A, Ferriss JB, Liddy C, Shanahan F, Feighery C: High prevalence of celiac disease among patients with insulin-dependent (type I) diabetes mellitus. Am J Gastroenterol 1997, 92:2210-2212

6. Talal AH, Murray JA, Goeken JA, Sivitz WI: Celiac disease in an adult population with insulin-dependent diabetes mellitus: use of endomysial antibody testing. Am J Gastroenterol 1997, 92:1280-1284

7. Acerini CL, Ahmed ML, Ross KM, Sullivan PB, Bird G, Dunger DB: Celiac disease in children and adolescents with IDDM: clinical characteristics and response to gluten-free diet. Diabet Med 1998, 15:38-44

8. Calero P, Ribes-Koninckx C, Albiach V, Carles C, Ferrer J: IgA antigliadin antibodies as a screening method for nonovert celiac disease in children with insulin-dependent diabetes mellitus. J Pediatr Gastroenterol Nutr 1996, 23:29-33

9. Rensch MJ, Merenich JA, Lieberman M, Long BD, Davis DR, McNally PR: Gluten-sensitive enteropathy in patients with insulin-dependent diabetes mellitus. Ann Intern Med 1996, I 24:564-567

10. Saukkonen T, Savilahti E, Reijonen H, Ilonen J, Tuomilehto-Wolf E, Akerblom HK: Coeliac disease: frequent occurrence after clinical onset of insulin-dependent diabetes mellitus. Diabet Med 1996, 13:464-470

II. Catassi C, Ratsch IM, Fabiani E, Rossini M, Bordicchia F, Coppa GV, Giorgi PL: Coeliac disease in the year 2000: Exploring the iceberg. Lancet 1994, 343:200-203

12. Hed J, Leden G, Ottoson E, Strom M, Walan A, Groth 0, Sjogren F, Franzen L: IgA anti- gliadin antibodies and jejunal mucosal lesions in healthy blood donors. Lancet 1986, 2:215

13. Atisook K, Madara JL: An oligopeptide permeates intestinal tight junctions at glucose- elicited dilatations: implications for oligopeptide absorption. Gastroenterology | 99|, | 00:7|9-724

14. Di Mario U, Anastasi E, Mariani P, Ballati G, Perfetti R, Triglione P, Morellini M, Bonamico M: Diabetes-related autoantibodies do appear in children with coeliac disease. Acta Paediatr 1992, 81:593-597

15. Volta U, De Franceschi L, Molinaro N, Tetta C, Bianchi FB: Organ specific autoantibodies in coeliac disease: do they represent an epiphenomenon or the expression of associated autoimmune disorders? Ital J Gastroenterol Hepatol 1997, 29: I8-2 I

16. Shanahan F, Mckenna R, McCarthy CF, Drury MI: Coeliac disease and diabetes mellitus: a study of 24 patients with HLA typing. QJM 1982, 5 1:329-335

17. Savilahti E, Simell 0, Koskimies S, Rilva A, Akerblom HK: Coeliac disease in insulin dependent diabetes mellitus. J Pediatr 1986, 108:690-693

18. Koletzko S, Burgin-Wolff A, Koletzko B, Knapp M, Burger W, Grüneklee D, Herz G, Ruch W, Thon A, Wendel U, Zuppinger K: Prevalence of coeliac disease in diabetic chidren and adolescents: a multicentre study. Eur J Pediatr 1988, 148:1 I3-1 I7
19. Cacciari E, Salardi S, Volta U, Biasco G, Partesotti S, Mantovani W, Cicognani A, Tassoni P, Pirazzoli P, Bianchi FB, Barboni F, Pisi E: Prevalence and characteristics of coeliac disease in type I diabetes mellitus. Acta Paediatr Scand 1987, 76:67I-672

20. Maki M, Huupponem T, Holm K, Hallstrom O: Seroconversion of reticulin autoantibodies predicts coeliac disease in insulin dependent diabetes mellitus. Gut 1995, 36:239-242

21. Collin P, Salmi J, Hallstrom 0, Oksa H, Oksala H, Maki M, Reunala T: High frequency of coeliac disease in adult patients with type I diabetes. Scand J Gastroenterol 1989, 24:8I-84

22. Barera G, Bianchi C, Calisti L, Cerutti F, Dammacco F, Frezza E, Illeni MT, Mistura L, Pocecco M, Prisco F, Sacchetti C, Saggese G, Stoppoloni G, Tonini G, Chiumello G: Screening of diabetic children for coeliac disease with antigliadin antibodies and HLA Arch Dis Child I99I, 66:49|-494

23. Page SR, Lloyd CA, Hill PG, Peacock I, Holmes GKT: The prevalence of coeliac disease in adult diabetes mellitus. QJM 1994, 87:631-637

24. Caselli M, Bovolenta MR, Aleotti A, Trevisani L, Stabellini G, Ricci N: Epithelial morphology of duodenal bulb and Campylobacterlike organisms. J Submicrosc Cytol Pathol I988, 20:237-242

25. Matsukura N, Suzuki K, Kawachi T, Aoyagi M, Sugimura T, Kitaoka $H$, Numajiri H, Shirota A, Itabashi M, Hirota T: Distribution of marker enzymes and mucin in intestinal metaplasia in human stomach and relation to complete and incomplete types of intestinal metaplasia to minute gastric carcinomas. J Natl Cancer Inst 1980, 65:231-240

26. Kato $Y$, Kitagawa T, Yanagisawa A, Kubo $K$, Utsude $T$, Hiratsuka $H$, Tamaki M, Sugano H: Site-dependent development of complete and incomplete intestinal metaplasia types in the human stomach. Jpn J Cancer Res 1992, 83:178-183

27. Genta RM, Gurer IE, Graham DY, Krishnan B, Segura AM, Gutierrez $0, \mathrm{Kim} J \mathrm{G}$, Burchette JL Jr: Adherence of Helicobacter pylori to areas of incomplete intestinal metaplasia in the gastric mucosa. Gastroenterology 1996, I I I:I 206-12 I I

28. Hamamoto T, Yokozaki H, Semba S, Yasui W, Yunotani S, Miyazaki K, Tahara E: Altered microsatellites in incomplete-type intestinal metaplasia adjacent to primary gastric cancers. J Clin Pathol 1997, 50:84|-846

29. Gottfried MR, McClave SA, Boyce HW: Incomplete intestinal metaplasia in the diagnosis of columnar lined esophagus (Barrett's esophagus). Am J din Pathol I989, 92:74I-746

30. Voutilainen M, Farkkila M, Juhola M, Mecklin JP, Sipponen P: Complete and incomplete intestinal metaplasia at the oesophagogastric junction: prevalences and association with endoscopic erosive oesophagitis and gastritis. Gut 1999. 45:644-648

31. Phillips AD, Brown A, Murch S, Walker-Smith JA: Histochemical studies of microvillous atrophy: acetylated sialic acid residues accumulate in the epithelium. J Pediatr Gastroenterol Nutr 1999, 28:565 (abstr)

32. Shabib SM, Cutz E, Drumm B, Sherman PM: Association of gastric metaplasia and duodenitis with Helicobacter pylori infection in children. Am J Clin Pathol 1994, 102:188-191

33. Cucchiara S, Franzesa A, Salvia G, Alfonsi L, lula V, Montisci A, Moreira FL: Gastric emptying delay and gastric electrical derangement in IDDM. Diabetes Care 1996, $21: 438-443$

34. Nowak TV, Roza AM, Weisbruch JP, Brosnan MR: Accelerated gastric emptying in diabetic rodents: effect of insulin treatment and pancreas transplantation. J Lab Clin Med 1994, I 23:1 I0-116

\section{Pre-publication history}

The pre-publication history for this paper can be accessed here:

http://www.biomedcentral.com/content/backmatter/ 1472-6890-1-2-b1.pdf 